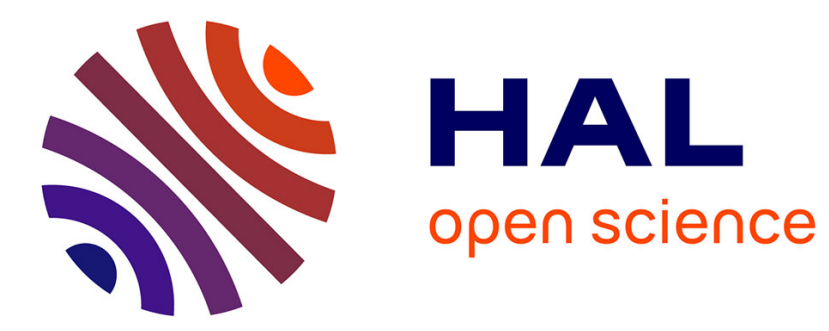

\title{
The waste crisis in Campania, South Italy: a historical perspective on an epidemiological controversy
}

\author{
Roberto Cantoni
}

\section{To cite this version:}

Roberto Cantoni. The waste crisis in Campania, South Italy: a historical perspective on an epidemiological controversy. Endeavour, 2016, 40 (2), pp.102-113. 10.1016/j.endeavour.2016.03.003 . hal-01285492

\section{HAL Id: hal-01285492 \\ https://hal.science/hal-01285492}

Submitted on 11 Mar 2016

HAL is a multi-disciplinary open access archive for the deposit and dissemination of scientific research documents, whether they are published or not. The documents may come from teaching and research institutions in France or abroad, or from public or private research centers.
L'archive ouverte pluridisciplinaire HAL, est destinée au dépôt et à la diffusion de documents scientifiques de niveau recherche, publiés ou non, émanant des établissements d'enseignement et de recherche français ou étrangers, des laboratoires publics ou privés. 


\section{THIS IS A DRAFT. PLEASE DO NOT CITE OR CIRCULATE IT PRIOR TO THE AUTHOR'S CONSENT}

\section{The waste crisis in Campania, South Italy: a historical perspective on an epidemiological controversy}

Roberto Cantoni ${ }^{\mathrm{a}}$

${ }^{a}$ LATTS - Ecoles des Ponts ParisTech/CNRS/UPEMV

Postal address:

16/20 boulevard Newton, Cité Descartes

Champs-sur-Marne 77447, Marne-la-Vallée cédex 2

France

E-mail address: roberto.cantoni@enpc.fr

Abbreviations $^{1}$

\section{Abstract}

Between 2001 and 2009, the area of Naples, South Italy, repeatedly hit the headlines of national and international media due to the waste management crisis that on many occasions filled up the streets of the region with huge piles of waste. What soon emerged as the main bone of contention concerned the connections between the population's health and the presence of dumps on the territory. What the risks for health actually were, who was entitled to assess them, and whether pollution from proximity to dumps caused health problems were all topics that came to the fore during a debate that took place within the Italian epidemiological community, alongside the political and governance crisis.

Keywords: waste management, epidemiology, Naples (Italy), agnotology

All scientific work is incomplete - whether it be observational or experimental. All scientific work is liable to be upset or modified by advancing knowledge. That does not confer upon us a freedom to ignore the knowledge we already have, or to postpone the action that it appears to demand at a given time. ${ }^{2}$

Austin Bradford Hill

\section{Introduction}

Acerra, outskirts of Naples, South Italy, 17 August 2004, about $1 \mathrm{pm}$. Two men cling to the top of a crane inside a building site, in the suffocating heat of a summer afternoon. At the foot of the crane, a group of people has gathered to support them: these are citizens from Acerra, a town of

\footnotetext{
AIE: Italian Epidemiology Association; CM: congenital malformations; CNR: National Research Council (Italy); E\&P: Epidemiologia \& Prevenzione; FFW: fuel-from-waste ; GNI: Gross National Income; ISS: National Institute of Health (Italy); Sebiorec: Studio Epidemiologico Biomonitoraggio Regione Campania; WHO: World Health Organization.

2 Austin Bradford Hill, "The Environment and Disease: Association or Causation?" Proceedings of the Royal Society of Medicine 58, no. 5 (May 1965): 300.
} 
55,000 , which is slated to host Europe's largest waste-to-energy incinerator. The two men on the crane are the mayor of Acerra, Espedito Marletta, and a Senator of the Italian Republic, Tommaso Sodano, both from the radical left party Rifondazione Comunista (Communist Reestablishment). Below the crane, beside the citizens, stands a group of people in uniforms: these are the deputy police commissioner of Naples, Antonio De Jesu, and his agents. De Jesu orders the two men on the crane to come down, but the two do not comply. Negotiations stall for a while, before De Jesu orders agents to intervene and disperse the protest. Marletta and Sodano are placed under arrest and brought to the police headquarters, where they are charged with invasion of private ground and threats against a public official.

The image of two state officers staging a blatant protest by challenging a body of the very state they represent is among the most emblematic of the waste management crisis that rocked the region of Campania and its capital, Naples, from 1994 to 2009. Especially after this incident in 2004, the crisis filled the pages of newspapers and news broadcasts, bringing to light, both nationally and internationally, an extremely complex network of processes and actors, and causing one of the longest-running media scandals in recent Italian history. Most contemporary Italian media would refer to it as the Campanian "waste emergency," because indeed a state of emergency had formally been declared in 1994. But apart from the legal phrasing, can a fifteen-year long process be called an emergency at all? And what did it entail for the Campanian society?

In the last decade, a number academic and journalistic publications have sought to respond to this and other unresolved questions related to the crisis. Legal, political, managerial, environmental, and sociological aspects have been scrutinized, as have the involvement of the local mafia - the camorra — and that of local and national administrations. ${ }^{3}$ The literature on the crisis brings to the forefront opinions and accounts of technology experts, policymakers, and

\footnotetext{
Though in international literature the word "mafia" tends to be indiscriminately attributed to a variety of criminal organisations, one should keep in mind that significant differences exist between, for example, the Sicilian mafia and the Neapolitan camorra, in terms of structure, organization, involvement in illegal activities, etc. For an initiation to the recent history of camorra, see: Francesco Barbagallo, Il potere della camorra (1973-1998) (Torino: Einaudi, 1999). On the mass media and the waste crisis, see: Rossella Savarese, Galli sulla monnezza. Silenzi, grida e bugie sui rifiuti in Campania (Roma: Franco Angeli, 2009).
} 
citizens living in the affected areas. ${ }^{4}$ Works by journalist Alessandro Iacuelli and engineer Paolo

Rabitti, for example, have scrupulously reconstructed the chronology, main legislative and political issues of the Campanian case, and detailed the roles and actions of actors involved. ${ }^{5}$

More reflexive works started to emerge towards the formal end of the crisis (December 2009), and aspects of the Campanian crisis have been analyzed by geographers, political scientists, and environmental scientists. Geographers have shown how the camorra progressively took control of the regional waste management sector by replacing the formal regulatory system with an informal one; surprisingly, however, much less academic interest has been shown towards illegal waste disposal activities by Northern and Central Italy's entrepreneurs. ${ }^{6}$ Political scientists have argued that delays in the transition to industrial treatment and recycling can be explained by institutional proliferation (i.e., ad hoc creation of a large number of public agencies to which to entrust urban waste management), clientelism, and unstable political executives who favored political expedience over technical expertise. ${ }^{7}$ While stressing major discrepancies between the data on produced and disposed waste in official statistics, economists have formulated a new system of environmental accounting to provide a more accurate assessment of the figures of waste generation and disposal in Campania, in contrast to analytical tools employed in official statistics. ${ }^{8}$

Other studies have provided more sociologically and anthropologically oriented

\footnotetext{
4 A summary selection of the most significant monographic sources on the crisis include: Alessandro Iacuelli, Le vie infinite dei rifiuti: il sistema campano (Altrenotizie.org/Lulu, 2007); Paolo Rabitti, Ecoballe. Tutte le verità su discariche, inceneritori, smaltimento abusive dei rifiuti. Testimonianza shock su Napoli e Campania (Reggio Emilia: Aliberti Editore, 2008); Antonello Petrillo (ed. ), Biopolitica di un rifiuto. Le rivolte anti-discarica a Napoli e in Campania (Verona: Ombre corte, 2009); Liliana Cori, and Vincenza Pellegrino, Corpi in Trappola - Vite e Storie tra i Rifiuti (Roma: Editori Riuniti, 2011); Marco Armiero (ed.), Teresa e le altre. Storie di donne nella terra dei fuochi (Milano: Jaca Book, 2014).

5 Iacuelli, Vie infinite; Rabitti, Ecoballe.

6 Fabrizio Maccuglia, "La Campanie, plaque tournante du trafic de déchets". Historiens \& Géographes, 403 (2008): 125-33. A second work by a geographer is: Vittorio Amato, "Conflitti ambientali e territorio. Alcune evidenze dalla crisi dei rifiuti in Campania”. In Tullio D’Aponte (ed.), Il cavallo di Troia. Disagio sociale, politiche carenti, marginalità diffusa nello sviluppo territoriale della Campania, 87-106 (2009, Roma: Aracne). However, this work appears based on rather simplistic argumentative lines when it embarks on a sociological analysis of the crisis.

7 Eleonora Pasotti, "Sorting through the Trash: The Waste Management Crisis in Southern Italy", South European Society and Politics 15 (2: 2010), 289-307.

8 Giacomo D'Alisa, Maria Federica Di Nola, and Mario Giampietro, “A multi-scale analysis of urban waste metabolism: density of waste disposed in Campania", Journal of Cleaner Production 35 (2012): 59-70; Giacomo D'Alisa and Marco Armiero, "La ciudad de los residuos. Justicia ambiental e incertidumbre en la crisis de los residuos en Campania (Italia)", Ecología política 41 (2011): 97-105; Id., "What Happened to the Trash? Political Miracles and Real Statistics in an Emergency Regime", Capitalism Nature Socialism 24 (4: 2013): 29-45.
} 
perspectives: the environmental history and sociology. ${ }^{9}$ Some scholars have sought to understand the relations between territory, populations, and waste, for example by analyzing the numerous mobilizations against incinerators and landfills in Campania. In particular, environmental historian Marco Armiero has included the Campanian issue within the framework of the environmental justice movement, which merges social and environmental issues: ${ }^{10}$ by framing the crisis within Italy’s historical post-"unification" context, ${ }^{11}$ he has shown the role of racialization in the Campanian issue, the contamination of the region's land being often summarily ascribed to a historical anthropological diversity—read, inferiority—of Southern Italians with respect to peoples of the rest of the peninsula. ${ }^{12}$ The racialization framing of the crisis allowed Armiero to liken struggles of Campanian citizens against the opening of landfills and incinerators to those of populations of the global South against industrial mega-projects, or those led by marginalized Afro-American communities in the US. ${ }^{13}$

Still other studies, countering a simplistic narrative ascribing Campanian mobilizations to technophobia or to a NIMBY (Not In My Back Yard) effect, have investigated citizens' protests in terms of a crisis of democracy, showing how resistance was prompted by institutional actors' neglect of any consultation and communication strategy with the affected populations, and their adoption of a technocratic, top-down decision-making agenda, ruled by institutional experts. ${ }^{14}$ In

9 William R. Catton, Jr. and Riley E. Dunlap, "Environmental Sociology: A New Paradigm”, The American Sociologist 13 (February 1978): 41-49; Riley E. Dunlap and William R. Catton, Jr., "Environmental Sociology", Annual Review of Sociology 5 (1979): 243-273.

10 See the articles included in: Capitalism Nature Socialism, 24 (4: 2013). For a theorisation of the Environmental Justice Movement, see: Joan Martinez-Alier, The Environmentalism of the Poor: A Study of Ecological Conflicts and Valuation (Northhampton, MA: Edward Elgar Publishing, 2002).

11 Italy's political 'unification' - in fact, the conquest by the Piedmontese armed forces of the states of the Italian peninsula - was ultimated by 1871 . The fall of the Kingdom of the Two Sicilies - and of it capital city, Naples occurred in 1861. The King of Sardinia-Piedmont, Victor Emmanuel of Savoy, was proclaimed King of Italy on 17 March 1861.

12 Marco Armiero, "Is there an indigenous knowledge in the urban North? Re/inventing local knowledge and communities in the struggles over garbage and incinerators in Campania, Italy", Estudos de Sociologia 1 (20: 2014$)$ (http://www.revista.ufpe.br/revsocio/index.php/revista/article/view/339/298, accessed 19 October 2015). On the issue of anti-Southern racism in Italy, see references in: Antonello Petrillo, "Le urla e il silenzio. Depoliticizzazione dei conflitti e parresia nella Campania tardo-liberale”. In Antonello Petrillo (ed. ), Biopolitica di un rifiuto. Le rivolte anti-discarica a Napoli e in Campania, 20-3 (Verona: Ombre corte, 2009).

13 Armiero, "Is the an indigenous knowledge". On enviromental racism and marginality, see: Robert Bullard, Dumping in Dixie: race, class, and environmental quality (Boulder : Westview Press, 1990); Sarah A. Moore, "The Politics of Garbage in Oaxaca, Mexico", Society and Natural Resources 21 (2008): 597-610; Zygmunt Bauman, Wasted Lives: Modernity and Its Outcasts (Hoboken : Wiley, 2014).

14 Articles included in Petrillo (ed.), Biopolitica di un rifiuto; Marco Armiero, "La natura sotto casa: le lotte per la giustizia ambientale con un caso di studio sulla Campania”, Ricerche Storiche, XLI (3: Sep-Dec 2011): 551-63; Marco Armiero and Giacomo D’Alisa, "Rights of Resistance: The Garbage Struggles for Environmental Justice in 
short, these works interpret mobilizations as community struggles or popular resistance

movements, capable of going beyond localism and extending their claims to a democratization of sociotechnical decision-making and a more general criticism of the contemporary development model.

Notwithstanding the extensive academic research on the Campanian crisis, very few authors have hinted at the issues of the production of expert knowledge in the process, or recognized the crisis as a paradigmatic example of a sociotechnical controversy, namely one combining a high rate of scientific technicality with social and environmental preoccupations. Those who have taken an interest in the science involved in the waste crisis, have highlighted the difference in attitude of the many stakeholders involved in the Campanian issue vis-à-vis the word of experts, or have focused on the disclosure of epidemiological data, on their appropriation by citizens and on the institutional consequences of such appropriation, or still, have stressed the activists' exploitation of the plurality of voices among experts. ${ }^{15}$ Whereas these works focused on conflicts between citizens and institutional experts, a further conflict persisted among those very experts: epidemiologists.

In reconstructing this controversy, my study contributes to an area of research stemming from a plea by sociologists Harry M. Collins and Robert Evans in the early 2000s, on the need for a "wave" of studies on experts and expertise. ${ }^{16}$ Collins and Evans's call to arms soon aroused the interest of a number of historians of science, technology, and medicine, as well as of

Campania, Italy", Capitalism Nature Socialism, 23 (4: 2012): 52-68; Id., "Voices, Clues, Numbers: Roaming Among Waste in Campania", Capitalism Nature Socialism, Capitalism Nature Socialism 24 (4: 2013): 1-10; Gianpaolo Di Costanzo and Stefania Ferraro, "The Landfill in the Countryside: Waste Management and Government of the Population in Campania", Capitalism Nature Socialism, 24 (4: 2013): 17-28; Marco Armiero, "Garbage Under the Volcano: The Waste Crisis in Campania and the Struggles for Environmental Justice", in Marco Armiero and Lise Sedrez (eds.), A History of Environmentalism. Local Struggles, Global Histories, 167-84 (London/New York: Bloomsbury, 2014). Against interpretations in terms of NIMBY, see: Danny Trom, "De la réfutation de l'effet NIMBY considérée comme une pratique militante. Notes pour une approche pragmatique de l'activité revendicative, Revue française de science politique, 49 (1: 1999): 31-50; Jacques Lolive, "La montée en généralité pour sortir du NIMBY. La mobilisation associative contre le TGV Méditerranée”, Politix 10 (39: 1997): 109-30.

15 Armiero, "Is there an indigenous knowledge", passim; Id., "Seeing Like a Protester", 65; Id., "Garbage Under the Volcano", 172, 176; Armiero (ed.), Teresa e le altre; Giacomo D’Alisa, David Burgalassi, Hali Healy, and Mariana Walter, "Conflict in Campania: Waste emergency or crisis of democracy", Ecological Economics 70 (2010): 239-49.

16 Harry M. Collins and Robert Evans, "The Third Wave of Science Studies: Studies of Expertise and Experience", Social Studies of Science 32 (2: April 2002): 235-96; Id., Rethinking Expertise (Chicago: University of Chicago Press, 2007). 
environmental historians, who have gradually started to reveal in their works the relations between scientific expertise, issues of legitimation and authority, credibility, lobbying activities, legislation, governmental and industrial policies and politics, and especially the production of scientific knowledge and ignorance. ${ }^{17}$ Although the area of the regulation of toxic products has been studied in terms of expertise and knowledge (and ignorance) production, this research strand has only marginally addressed the issues raised by waste and waste management.

The production of expertise, knowledge, and ignorance was at the core of the debate that, in the early 2000s, kept many Italian epidemiologists busy assessing whether living close to dumps and incinerators was harmful to human health. Epidemiologists were entrusted with the complex but crucial task of providing the evidence-based arguments that would bolster the edifice of political decision-making. In theory, one would expect that the response to questions such as whether measures on health and safety should be taken to confront the crisis; what kind of provisions these should be; and what form of policies should be implemented to protect citizens' health, would depend to some extent on the epidemiologists' assessment of the links between waste, human health, and the environment. In the Campanian case, however, the translation from theory to practice followed a winding and convoluted path.

Whereas from the epidemiological stance that path would allow the establishment and consolidation of new scientific and medical knowledge, from the political viewpoint the end of the path would end up rather close to its beginning. The uncertainty intrinsically characterizing scientific knowledge was construed by the national government — and in particular by the Ministry of Health — as a pretext for minimizing actions to be taken in devising countermeasures to the crisis. In addition, during the epidemiological controversy, the strategy chosen by institutions to

\footnotetext{
7 A summary list of works includes: Gerald Markowitz and David Rosner, Deceit and Denial. The Deadly Politics of Industrial Pollution (New York: University of California Press and Milbank Books, 2002); Robert N. Proctor and Londa Schiebinger, Agnotology: The Making and Unmaking of Ignorance (Stanford: Stanford University Press, 2008); Naomi Oreskes and Erik M. Conway, Merchants of Doubt: How a Handful of Scientists Obscured the Truth on Issues from Tobacco Smoke to Global Warming (London: Bloomsbury Press, 2010); Thomas Le Roux, Le laboratoire des pollutions industrielles: Paris, 1770-1830 (Paris: Albin Michel, 2011); Gerald Markowitz and David Rosner, Lead Wars. The Politics of Science and the Fate of America's Children (New York: University of California Press and Milbank Memorial Fund, 2013); Soraya Boudia and Nathalie Jas (eds.), Toxicants, Health and Regulation since 1945 (London: Pickering \& Chatto,. 2013); Id. (eds.) Powerless Science? Science and Politics in a Toxic World (London: Berghahn Books, 2014).
} 
communicate the developing scientific knowledge to Campanian citizens was highly insufficient, and dictated by a technocratic rationale; and although epidemiologists would recommend that policymakers address the affected communities' legitimate worries, efforts to do so would instead infantilize community members and brand their anxiety as irrational and egoistic. It is to an analysis of the production of epidemiological knowledge and ignorance in the Campanian case that I now turn, after sketching a brief chronology of the crisis.

\section{A socio-demographic introduction to Campania and the chronology of the "emergency"}

The southern Italian region of Campania (Fig. 1) is the country's second largest by population, with almost six million people, roughly $10 \%$ of the Italian population. The Province of Naples hosts most of the region's citizens, and it is Italy's third-largest province by population, with slightly over three million. Campania is also Italy's most densely populated region (429 people $/ \mathrm{km}^{2}$ ), and the Province of Naples is by far the most densely populated province in Italy, with slightly over 2,600 people $/ \mathrm{km}^{2}$ (by comparison, the Province of Milan, the second most densely populated large province, has a density of about 2,000). In spite of this demographic data, however, Campania is third last among the Italian regions in terms of per-capita waste production. ${ }^{18}$ It may therefore appear surprising that this region hosted the longest and most bitter waste management crisis in the history of contemporary Italy.

Fig. 1. Provinces of Campania

The picture is clarified by what are the most striking indicators about the region. First, is its per-capita Gross National Income (GNI), which, at €14,422, makes Campania the second-poorest region in Italy (by comparison, Aosta Valley, Italy's richest region, has a per-capita GNI of

18 Data on per capita waste production refer to 2013. ISPRA, Rapporto Rifiuti Urbani, Edizione 2014 - Dati di sintesi, vol. 202/2014, pp. 26-7. 
$€ 30,843)$. Second, the "Density of Waste to be Disposed of" rate-indicating the amount of waste disposed of per day in a given area—in which Naples ranks as the highest Province in Italy. ${ }^{19}$

Comparing the latter index with the region's generalized poverty, it is perhaps easier to understand some of the problems that characterize the region in terms of management of services and infrastructures.

According to the environmentalist association Legambiente, Campania is also the Italian region presenting the highest occurrence of environmental crimes $(16 \%$ of the national total in 2014), ${ }^{20}$ largely a result of the activities of the camorra. Beginning in the 1980 s, the camorra turned illegal waste management into a lucrative business, by forming criminal joint ventures with a number of Northern and Central Italian industrialists, so as to bury hazardous waste from that part of the country in southern regions by offering extremely advantageous economic incentives. ${ }^{21}$ According to Iacuelli, in the late 1980s and early 1990s, a series of ship accidents, and the following judicial investigations, exposed an international traffic of radioactive waste from North Italy to countries like Mozambique, Nigeria, Romania, Somalia, and Venezuela. As a consequence of the first revelations, and of the heightened attention of the Italian judiciary, entrepreneurs involved in the traffic were forced to find new ways to dispose their waste without crossing national borders. This was made possible by the 1989 secret "Villaricca meeting." On that occasion, some members of the Italian Liberal Party met members of the Freemasonry, a number of chiefs of the Casalesi camorra clan, and a number of figures connected to local waste disposal enterprises, in Villaricca, a town close to the Campanian city of Caserta. ${ }^{22}$

One of the people present at the meeting was the middleman between the Casalesi clan and Licio Gelli, the main leader of the P2 Masonic lodge, who could boast a wide network of contacts

19 Data on per-capita GNI are from 2012. Source: Istituto Nazionale di Statistica, 'Pil pro capite' (http://noiitalia.istat.it/index.php?id=7\&user_100ind_pi1\%5Bid_pagina $\% 5 \mathrm{D}=91$, accessed 19 October 2015). The DWD index for the Province of Naples is $3525[\mathrm{~kg} / \mathrm{day}] / \mathrm{km}^{2}$ - that is, twice times the value of the Province of Milan, the other Italian metropolitan area with an extremely high DWD. Source: D'Alisa, Di Nola, and Giampietro, “A multi-scale analysis", 65 .

20 Legambiente, Rapporto Ecomafia 2014, http://www.legambiente.it/contenuti/dossier/rapporto-ecomafia-2014, accessed 21 October 2015.

${ }^{21}$ Iacuelli, Vie infinite; Roberto Saviano, Gomorra. Viaggio nell'impero economico e nel sogno di dominio della camorra (Milano: Mondadori, 2006).

22 Iacuelli, Le vie infinite, 21-7. 
with a number of Northern Italy entrepreneurs, interested in finding new avenues to get rid of their waste at a low cost. The aim of the meeting was to define a grand plan for illegal waste disposal: the final agreement planned that the camorra would offer the disposal services to Northern entrepreneurs at below-market costs through its own transport company. This company was to be authorized by the regional Counselor for Ecology, a member of the Liberal Party, in exchange for a significant percentage of the camorra's revenues. ${ }^{23}$ As such the waste crisis represents not so much a criminal aberration, but rather the way in which capitalism was expanding its profits through the socialization of costs. Initially, both urban and toxic waste were transported and abandoned in illegal dumps. As the market grew larger, the system increased its complexity: measures implemented by legal institutions to monitor waste disposal were not able to improve the situation, which reached a point of no return in 1994, when regional public dumps were declared saturated.

Aside from camorra activities (from the mid-1990s, mafia-like organizations involved in environmental crime were usually referred to as eco-mafias), the legal waste management cycle in Campania has been characterized by long-term approximation and malpractice, delays in planning and managing adequate dumps, inadequate processing of urban waste in dedicated plants, and by the lack of well-designed schemes for waste recycling. In 2007, to mention one figure, recycling in the Province of Naples added up to as little as $8 \%$ (in 2013, however, this percentage had risen to $38.5 \%) .{ }^{24}$ Until the mid-2000s, scarcity of data on the effects of the mismanagement of the waste cycle on populations was also a factor.

The waste "emergency" in Campania is conventionally understood to have started in February 1994, with the entry into force of a decree by Prime Minister, Carlo Azeglio Ciampi (Fig. 2). ${ }^{25}$ Through this provision, the Italian government acknowledged the existing environmental emergency in many Campanian dumps, due to the saturation of a number of them. A special commission was constituted to manage the emergency, and an emergency manager (commissario straordinario) was appointed and asked to formulate a regional plan for waste disposal. Some

\footnotetext{
23 Ibid., 32-3

24 APAT (2007); ISPRA, Rapporto Rifiuti Urbani, Edizione 2014, p. 55.

25 Presidential Decree of 11 February 1994, published on the Official Gazette n. 35, 12 February 1994.
} 
measures were implemented, but they were not sufficient to stop the emergency, so that the Regional Governor was appointed as new emergency manager in 1996. In July 1997, the Governor published a Region Plan for waste disposal, including the construction of two waste-to-energy incinerators and seven fuel-from-waste (FFW) production plants.

Fig. 2. Summary chronology of the Campanian waste crisis (adapted from Armiero, "Is There an Indigenous Knowledge in the Urban North?”)

The Governor then launched a call to find an enterprise to which to entrust the entire waste management cycle and build the dedicated infrastructures by 2000 . The project was finally assigned to an Italian-German consortium, FIBE, by privileging criteria of building speed and cost minimization. To speed up the procedure, the Governor used his extraordinary powers, reflecting a state of emergency, which allowed him to ignore the general requirements for environmental impact assessment regulations that would have been otherwise mandatory for building the infrastructures. This decision accelerated the implantation of the facilities and played into the hands of FIBE, to which the tender delegated in addition the unusual right to choose the sites to locate its plants. ${ }^{26}$ The public sector washed its hands of the entire problem by entrusting its powers to a corporation, in what turned out to be "a daring experiment in ultra-liberal governmentality. ${ }^{, 27}$ Eventually, FIBE failed to fulfill its contract: by the end of 2000 there was no sign of incinerators, and the FFW plants built between by 2001 only produced "eco-bales" (namely, packages of compacted waste, Fig. 3), which were too humid to burn in incinerators. By 2008, these unusable eco-bales, stocked in unsuitable sites and exposed to atmospheric agents, amounted to six million tons.

Mainly because of FIBE's mismanagement and the slowness in devising waste recycling programs, there was a crisis in waste collection at the beginning of 2001. It was only solved by

26 Iacuelli, Le vie infinite, $125 \mathrm{ff}$.

27 Ciro Tarantino, "Strane confessioni. Memoria su alcuni casi di licenziosità nella Napoli del XXI secolo", in Petrillo (ed.), Biopolitica di un rifiuto, 210. 
opening old dumps and sending Campanian waste to other Italian regions and to Germany.

Although seven FFW plants were opened between 2001 and 2003, the lack of incinerators at which to burn refuse-derived fuel, and of recycling programs meant Campania had to continue using dumps and opening new ones, thus arousing intense citizen mobilizations in the affected areas. These mobilizations often degenerated into violent clashes with the police. The crisis reached its peak in 2007, at which time the government, led by Romano Prodi, selected more sites for dumps and authorized the construction of three new incinerators.

However, the envisaged cure threatened to be worse than the disease, since the choice of building incinerators with a view to solving the crisis was a hotbed of controversy, and not only among the population, but also among the epidemiological community. Uncertainties and strong disagreements simmered over the global consequences of the presence of incinerators on human health; over the kind of emissions generated by plants; and over the technology (older or newer generation) used for the plants. ${ }^{28}$ Moreover, the choice of the dump sites, in already socioeconomically depressed areas close to Naples, further alienated local populations, with serious repercussions for public order. Indeed, the history of the crisis shows that the government consistently chose the most vulnerable and socio-economically deprived areas for the construction of landfills and incinerators, wrongly assuming — according to Armiero — that people in these areas would be "too poor, too ignorant, or too polluted to react." 29

Fig. 3. "Eco-bales" approximately wrapped up in plastic and stocked in a Campanian site

28 Marco Caldiroli, "Impatto ambientale dei processi di incenerimento di rifiuti”, Epidemiol. Prev. (1: 2004): 48-56; Fabrizio Bianchi and Fabrizio Minichilli, "Mortalità per linfomi non Hodgkin nel periodo 1981-2001 in 25 comuni italiani con inceneritori di rifiuti solidi urbani”, Epidemiol. Prev. (2: 2006): 80-1; Nunzia Linzalone and Fabrizio Bianchi, "Inceneritori: non solo diossine e metalli pesanti, anche polveri fini e ultrafini", Epidemiol. Prev. (1: 2007): 62-6; Id., "Il contributo della VIS nella definizione delle politiche di gestione dei rifiuti a partire dal caso degli inceneritori", Epidemiol. Prev. (3: 2009): 113-5; AIE, "Trattamento dei rifiuti e salute. Posizione dell'Associazione italiana di epidemiologia. 6 maggio 2008”, Epidemiol. Prev. (4-5: 2008): 183-7. Heavily critical positions about building incinerators were expressed in: Michelangiolo Bolognini et al., "Critiche al seminario OMS-Europa sui rifiuti”, Epidemiol. Prev. (2: 2008): 79-80; Michelangiolo Bolognini et al., "Lettera aperta ai colleghi dell’AIE sul documento "Trattamento dei rifiuti e salute"'. Epidemiol. Prev. (4-5: 2008): 188.

29 Marco Armiero, "Seeing Like a Protester", Left History 13 (1: 2008): 65. 
In 2008, the new government led by Silvio Berlusconi approved a Legislative Decree that increased to four the number of incinerators to be built and identified ten new dump sites. These were declared areas of national strategic interest and militarized. Any demonstration in proximity to dumps was constituted a felony. ${ }^{30}$ Thus, through "exceptional" legislative measures, echoing Giorgio Agamben's argument that the state of emergency is a typical state of exception-in that ordinary regulations and democratic rights of citizens were suspended, and the border between a democratic and an absolutist state tended to become blurred-protesters were now likened to criminals hindering the operations of the government. ${ }^{31}$ Their activities were no longer considered legitimate opposition, but illegal subversion. ${ }^{32}$ The new decree, however, by eschewing all existing norms, including communitarian regulations, authorized the disposal of hazardous waste in the new dumps.

In 2009, after the opening of the first and only incinerator at Acerra, the government declared the end of the state of emergency via legislative decree, in spite of the lack of additional planned incinerators, of an adequate waste-recycling program, and of the continued stockpiling of eco-bales in the region. In fact, even the Acerra incinerator was never to work to its full capacity, and was to burn normal waste instead of FFW, thus causing emissions of particulate matter well over the authorized threshold. ${ }^{33}$ Witnessing the fact that the issue had only been solved de jure, in 2010 a further waste crisis was recorded, which was only resolved in early 2011.

Throughout the crisis, citizen protests were the most visible component of the issue, and surely its most mediatized element, as emerges from a content analysis in the national edition of one of Italy's most widely read and influential newspapers, la Repubblica. ${ }^{34}$ Clashes between protesters and security forces were paralleled by a second, less visible and more technical issue:

\footnotetext{
Legislative Decree n. 90 of 23 May 2008, converted into Law n. 123 of 14 July 2008.

1 Giorgio Agamben, Stato di eccezione (Torino: Bollati Boringhieri, 2003); Maccuglia (2008).

2 Serafina Ruggiero, "Chiaiano e i nuoi irregolari”, in Petrillo (ed.), 107.

33 Marco Molino, “Emissioni nocive oltre i limiti ad Acerra”, Il Sole 24 Ore, 27 May 2009. Molino's article was based on data from the Regional Agency for Environmental Protection of Campania (available at: http://www.ilsole 24ore.com/art/SoleOnLine4/Italia/2009/05/report-arpac-acerra.shtml?uuid=d04e11a6-4ab8-11de-b2194e35f9c290e3, "I report dell'Arpac sulle emissioni del termovalorizzatore di Acerra", Il Sole 24 Ore, accessed 21 October 2015.

34 Roberto Cantoni, "Comunicare il rischio per la salute durante l'emergenza rifiuti in Campania: la fase 2004-2008". Master's dissertation in Science Communication, SISSA-ISAS, Trieste, 2011, p. 151.
} 
that of the assessment of the impact of landfills on human health. The spark that ignited the controversy came not from Italy, but from the UK, more precisely from the pages of the Lancet Oncology, the world's leading medical journal, in the summer of 2004.

\section{The triangle of death}

In late August 2004, following a period of intense mobilization by the populations residing close to new designated landfills, The Lancet Oncology published a report by news writer Kathryn Senior and Alfredo Mazza, a young researcher at the Clinical Physiology Institute of Pisa, which was part of the National Research Council (CNR). ${ }^{35}$ According to the report, the occurrence of some types of cancer recorded by one of the Local Health Agencies located in the Naples area was worrying. The concerned district was characterized by one of the worst records of illegal environmental activity in Italy, largely due to camorra-managed activities. Senior and Mazza noted that the data showed that mortality for colorectal and liver cancer, leukemia, and lymphoma, were higher there than in the rest of Campania and Italy. Mazza in particular was convinced of the link between the level of pollution caused by inadequate waste-control methods plus illegal dumping and the high level of cancer mortality in the region.

The report circumscribed the geographical area characterized by the highest environmental risk to the triangle between the Neapolitan towns of Acerra, Nola, and Marigliano (Fig. 4): the zone was nicknamed "the triangle of death" (il triangolo della morte) in the article. The catchy title immediately caught the attention of the press. It was true that by the time of the report's publication, the situation of Campanian dumping sites had already caused concern: for example, in July 2004 the European Commission had sent Italy a number of warning letters related to twentyeight cases of violation of the European Union's (EU) environmental laws. In those letters, most criticism was addressed to the thousands of illegal and uncontrolled dumps present in Italy. In

35 Kathryn Senior and Alfredo Mazza, "Italian 'Triangle of death' linked to waste crisis", The Lancet Oncology 5 (September 2004): 525-7. 
addition, by that time Italy had already been warned twice for flaunting the regulations of the Hazardous Waste Directive and the Landfill Directive, to the point that the EU referred Italy to the European Court of Justice for further action. ${ }^{36}$ Italy was eventually to be condemned in 2010 for failing to adopt sufficient measures to safeguard the safety of the population and the environment. ${ }^{37}$ The report nonetheless brought these issues to greater prominence.

The report caused a sensation in a situation that was already critical in terms of public order. It made headlines in all the leading papers in the country. It would soon become the most cited source of evidence throughout the crisis, and it remains so, a decade after its publication. It suddenly awoke the interest of institutions that had remained indifferent theretofore, and raised important questions about the health of Campanian citizens. But the triangle of death report had some serious problems: the methodology it employed appeared controversial. ${ }^{38}$ And there was more: it was a journalistic report, not a peer-reviewed article. But it had been published in The Lancet, which conferred to it a high degree of authority among non-specialists.

Fig. 4. The triangle of death, as represented in Senior and Mazza's reportage

Indeed, immediately after the article's main thesis was reported by la Repubblica, ${ }^{39}$ its methodology was contested by a group of epidemiologists from the CNR, led by Fabrizio Bianchi, who in a letter to the Lancet, warned about the flaws that compromised Senior and Mazza's study. The main mistake the two authors had made, according to the CNR researchers, consisted in basing their claims on an excessive concentration and an a priori choice of geographical delimitation. ${ }^{40}$ Thus Senior and Mazza risked neglecting areas outside the chosen one, which might have shown equally alarming indices, and might be even more affected than the one included in

36 Ibid., 525.

37 Unknown author, "Rifiuti in Campania, Italia condannata. 'Messi in pericolo l'uomo e l'ambiente"”, Corriere della Sera, 4 March 2010.

38 Fabrizio Bianchi, Pietro Comba, Marco Martuzzi, Raffaele Palombino, and Renato Pizzuti, "Italian 'Triangle of death",, The Lancet Oncology 5 (December 2004): 710.

39 Giuseppe Del Bello and Maria Novella De Luca, "Discariche piene di rifiuti tossici, quello è il triangolo della morte", la Repubblica, 31 August 2004.

40 Bianchi et al., "Italian 'Triangle of death", 710. 
the triangle. Within the triangle itself, the team contended, the pattern of early mortality and congenital malformations (CM) appeared to be heterogeneous.

A much more serious shortcoming of the report was that the claim of a link between waste disposal sites and human health was rushed, misleading, and disproportionate to the data used in the paper. The reply by Bianchi and colleagues was nothing less than an accusation that Mazza had committed scientific malpractice. The accusation was perceived as all the more serious because Mazza was, like his accusers, a researcher at CNR's Institute of Clinical Physiology. The use of a biased methodology — together with the lack of prior consultation with colleagues — could be seen as a blow to the institute's reputation. It certainly gave the impression of a lack of collaboration among researchers from the same institution. However, the CNR epidemiologists' reply to Senior and Mazza did not receive the same degree of interest by the mainstream media: in fact, it received none, conforming to the journalistic adage that the first news release is what count most. ${ }^{41}$

Why did Mazza limit his study to the area of Acerra-Nola-Marigliano? It appears that already in June 2004, journalist Conchita Sannino, writing for la Repubblica, had nicknamed the triangle between Acerra, Nola and Marigliano the "triangle of poisons" (triangolo dei veleni). ${ }^{42}$ Such characterization may imply that this phrase was already common in the area, and it may have favored a biased geographical delimitation of the area to study. What also irritated the CNR team was that Mazza's report risked fueling controversy and jeopardizing the ongoing epidemiological work. Indeed, although Mazza's data may have been the first to be reported in the media, other researchers had been working for several years on the links between landfills and health in the Provinces of Naples and Caserta.

An exploratory study from 2001 cross-referenced the distribution of childhood mortality in the Province of Caserta with the presence of acknowledged landfills. ${ }^{43}$ In that year, the study was

41 Liliana Cori, "Finalità e criticità del processo di comunicazione", in Fabrizio Bianchi and Pietro Comba (eds.), Indagini epidemiologiche nei siti inquinati: basi scientifiche, procedure metodologiche e gestionali, prospettive di equità. Rapporti ISTISAN 06/19 Rev., 105 (Roma: Istituto Superiore di Sanità, 2006).

42 Conchita Sannino, "I veleni di Acerra, Nola, Marigliano", la Repubblica edizione Napoli, 10 June 2004.

43 Stefania Trinca et al, "Childhood mortality in an area of southern italy with numerous dumping grounds: application of GIS and preliminary findings". In: First European Conference "Geographic Information Sciences in public Health". Sheffield, University of Sheffield, 19-20 September 2001. 
presented at an international conference in the UK, but partial results were only published in 2004 within a publication by the National Institute of Health (ISS) dedicated to the evaluation of environmental and health risk with regard to urban and hazardous waste disposal. ${ }^{44}$ But the conclusions of the ISS report were nuanced, and the peculiarities of Campanian landfills (presence of a high number of illegal disposal sites) were drowned within the more reassuring national context. In addition, this publication was in Italian, and was part of a series of reports released by the ISS yearly: grey literature read principally by specialists. The ISS report was no Lancet, and its resonance remained limited.

So too was the influence of another study, published in Italian in Epidemiologia \& Prevenzione (E\&P), an organ of the Italian Epidemiology Association (AIE), by researchers from seven national and regional health and environment institutions, and also including some of the authors of the 2001 study. $^{45}$ This was a mortality study of three Campanian municipalities characterized by a high concentration of legal and illegal waste disposal sites: it highlighted an excess of risk for a number of cancer pathologies, diabetes, and circulatory diseases, compared to the rest of the region, and suggested that improvements in exposure assessment together with the use of a range of health data would contribute to more thorough studies aimed at inferring causal relationships. Significantly, the paper concluded by inviting institutions to communicate with the population in order to contribute to a climate of mutual trust between technicians and the affected communities, and build informed consensus on decision-making. ${ }^{46}$

Results from these early studies may have been based on limited data, and no one dared to frame the issue in terms of a causal link, but they did recommend that governmental institutions intervene in some way in the problem of the landfills. In this respect, the alarm launched by the Director of E\&P, Benedetto Terracini, was unambiguous: "There are no doubts: intervention is necessary," he wrote in an editorial. Action was urgent, he claimed, given the quantity and quality

44 Mirella Bellino et al, "Caratterizzazione ambientale dei siti di discarica oggetto dello studio", in Loredana Musmeci (ed.), Valutazione del rischio sanitario e ambientale nello smaltimento di rifiuti urbani e pericolosi. Rapporti ISTISAN 04/5, 7-59 (Roma: Istituto Superiore di Sanità, 2004).

45 Pierluigi Altavista et al, "Mortalità per causa in un'area della Campania con numerose discariche di rifiuti", Epidemiol. Prev. 28 (2004): 311-21.

46 Ibid, 321. 
of available data. ${ }^{47}$ Although further studies were needed, there was no point in indefinitely postponing the reclamation of lands or the implementation of firm measures to favor an adequate waste management cycle. The time necessary to find that causal link could be too long for the recovery of lost health and environment to be still viable. Unfortunately, both the suggestion about devising a communication strategy and the one about intervening with reclamation programs would remain dead letters. But deeper studies were carried out.

\section{Joining forces for deepening studies}

In the same year the triangle of death was published, but before its publication, a multidisciplinary group was entrusted by the National Department of Civil Protection to investigate the health impact of waste in the Provinces of Naples and Caserta (referred to as "the multi-institutional study" henceforth). The group included researchers from the World Health Organization (WHO), the ISS in Rome, the Health and Environment Agencies of the Campania Region, and the CNR. The data the group collected were more thorough than those used in the Lancet report. This study included larger areas; it needed the group members' prior consultation before advancing any result, and it followed the usual path of scientific studies. An early feasibility study by the multiinstitutional group analyzed data regarding mortality and the incidence of $\mathrm{CM}$ at a municipal level: twenty cancer causes and eleven typologies of CM were considered, for which evidence could be found in the literature of some kind of association with landfills and incinerators. The results of this pilot study were presented in January 2005 in Naples, as well as at a number of international

\footnotetext{
7 Benedetto Terracini, "Discariche, triangoli e aree calde". Epidemiol. Prev. 28 (6: 2004): 299-300.
} 
conferences ${ }^{48}$ and they were published on the Civil Protection website, ${ }^{49}$ in the ISS Bulletin, ${ }^{50}$ and in an international journal. ${ }^{51}$

The study identified an area characterized by particularly high rates of mortality and some types of cancer: significantly, it extended far beyond the boundaries of the Lancet's triangle to include municipalities on the border between the Provinces of Naples and Caserta and some coastal towns in the area of Mount Vesuvius. The data showed an excess of mortality of $19 \%$ for men in the Province of Caserta and $43 \%$ in the Province of Naples. Data for women were even more alarming (23\% for Caserta, $47 \%$ for Naples).$^{52}$ The pilot study concluded that the areas characterized by the highest mortality and CM rates largely coincided with those where illegal landfills and sites of uncontrolled waste disposal were found. A large part of the identified area was included in what was popularly known as the "land of fires" (terra dei fuochi), a region characterized by mafia activities, such as frequent arsons of waste and illegal toxic waste dumps. However, the authors cautioned, it was hard to establish a causal link as the area was also characterized by intensive industrial and agricultural activities and a high population density.

While the epidemiological study was developing, epidemiologists became interested in the popular protest against landfills, and to the arguments formulated by citizens in this respect in particular. The development of this lay expertise was captured in an article by science

48 Marco Martuzzi et al, "Health impact assessment of waste in Campania, southern Italy". IAIA, Boston, MA, 31 May - 3 June 2005; Fabrizio Bianchi et al, "Waste in Campania region, Italy". XXVII IEA World Congress of Epidemiology: Epidemiology and equity in health: methodological challenges an strategies for the $21^{\text {st }}$ century, Bangkok, 21-25 August 2005; Marco Martuzzi et al, "Waste and health in souther Italy”. ISEE, Johannesburg, 13-16 September 2005; Marco Martuzzi et al, "Patología neoplástica y malfomaciones congénitas en las Provincias de la Campania con mayor presenzia [sic] de [sic] descargas", in Philip Landrigan et al (eds.), Salud ocupacional y ambiental: realidades diversas, Memorias de la conferencia international: Salud ocupacional y ambiental: emergencias en los países en desarrollo, Quito, 6-10 March 2006. 269-74; Marco Martuzzi et al, "Waste and health in southern Italy”. Spatial Epidemiology Conference, London, 23-25 May 2006.

49 WHO Regional Office for Europe et al, "Trattamento dei rifiuti in Campania: impatto sulla salute umana. Studio Pilota. Malformazioni congenite nelle province di Napoli e Caserta (1996-2002): analisi descrittiva e struttura spaziale del rischio", 2005; Id., "Trattamento dei rifiuti in Campania: impatto sulla salute umana. Studio Pilota. Mortalità per tumori nelle province di Napoli e Caserta (1994-2001): analisi descrittiva e struttura spaziale del rischio", 2005 (both documents are no longer available on the Civil Protection's website, but a synthesis of both is found on the ISS epidemiological observatory's website, EpiCentro: http://www.epicentro.iss.it/temi/ambiente/notepernapoli26012005.pdf, "Trattamento dei rifiuti in Campania: impatto sulla salute umana. Studio Pilota. Sintesi dei risultati e indicazioni preliminari”, accessed 20 October 2015).

50 Martuzzi et al, "Patologia neoplastica e malformazioni congenite nelle province della Campania con maggiore presenza di discariche. Notiziario Istituto Superiore di Sanità 18 (6: 2005): 3-8.

51 Pietro Comba et al, "Cancer Mortality in an Area of Campania (Italy) Characterized by Multiple Toxic Dumping Sistes", Annals of the New York Academy of Sciences 1076 (September 2006): 449-61.

52 WHO Regional Office for Europe et al, "Trattamento dei rifiuti in Campania: impatto sulla salute umana. Studio Pilota. Sintesi dei risultati e indicazioni preliminari”, 1. 
communicator Cinzia Colombo, also published in $E \& P .{ }^{53}$ Colombo interviewed a number of the activists who had most strongly engaged in the mobilizations of 2004; for example, citizens of Acerra, who justified their opposition to the incinerator by citing the authorities' lack of consultation with local populations, as well as the priority given by the authorities to incinerators rather than recycling and by the already precarious conditions of the Acerra ecosystem. Citizens opposing the opening of new dumps were generally accused of NIMBYism by national newspapers. To overcome this perception, they grounded their opposition in scientific arguments. They provided data showing that the sites chosen by institutional agencies were almost always disused sites against regulations, inadequate for structural, geographic, and especially for sanitary reasons, and that, in addition, those disused caves had often already been used by the camorra, which had buried there large amounts of highly carcinogenic industrial waste. ${ }^{54}$

Citizens were helped in this activity of knowledge co-production by a number of experts, who sympathized with activists' struggles, and with whom a synergy started to develop. In 2005, activists re-activated a public assembly initiative, which had been dormant since the late 1990s, the Assise della città di Napoli, which brought together experts from different fields to discuss aspects of the waste crisis on a weekly basis. Thus, as highlighted by Armiero, citizens were indeed developing their own scientific expertise, their "street science." ${ }^{55}$ More generally, in scientific controversies such as those on environmental health science, sustainable agriculture, extractive industry, or biomedical research, interactional expertise can be conceptualized as a form of extended peer-review of policy processes, or informal assessment of technology. ${ }^{56}$

On the official expertise side, some controversial methodological issues gradually started to

53 Cinzia Colombo, “Sono tutte ecoballe. Come uscire dall'emergenza rifiuti in Campania?" Epidemiol. Prev. 29 (1: 2005): 61-2.

54 Ibid.

55 Armiero, "In there an indigenous knowledge"; Id., "Garbage Under the Volcano", 176; Jason Corburn, Street Science. Community Knowledge and Environmental Health Justice (Cambridge, MA: MIT Press, 2005), 44.

56 Arie Rip, "Controversies as informal technology assessment”, Social Policy 14 (1983): 3-18; Silvio O Funtowicz, Jerome R Ravetz, "Science for the post-normal age”, Futures 25 (7: 1993): 739-55; Steven Epstein, "The Construction of Lay Expertise: AIDS Activism and the Forging of Credibility in the Reform of Clinical Trials", Sci. Technol. Hum. Val. 20 (4: 1995): 408-37; Michel S. Carolan, "Sustainable agriculture, science and the co-production of 'expert' knowledge: The value of interactional expertise", Local Environment 11 (4: 2006): 421-31; Jason Corburn, "Community knowledge in environmental health science: co-producing policy expertise", Envir. Sci. Pol. 10 (2: 2007): 150-61; George C Homsy, "Climate Change and the Co-Production of Knowledge and Policy in Rural USA Communities”, Sociol. Ruralis. 53 (3: 2013): 291-310. 
emerge. Data originating from cluster analysis concerning CM and exposure to polluted sites was certainly useful to epidemiology, and the fact that some of those analyses reported positive associations may have been indicative; nevertheless, only in a few cases were these studies statistically powerful or mutually consistent enough to support specific hypotheses. ${ }^{57}$ In addition, international results on excesses of risk for cancer, mortality, and CM, seemed to be in discord. ${ }^{58}$ Such shortcomings prompted some researchers to suggest the use of new and more refined tools of investigation, aimed at assessing individual exposure through biological indicators (biomonitoring) and environmental data, and able to control for confounding variables (such as socio-economic factors). Together with the indications coming from the multi-institutional study, the idea of using biomonitoring and applying it to the Campanian case would materialize in one of Europe's largest epidemiological studies: the Studio Epidemiologico Biomonitoraggio Regione Campania, providentially abbreviated as Sebiorec.

\section{A hotbed of controversy}

The final version of the multi-institutional study was published in 2007: the analysis of general mortality, tumors, and CM over all of the 196 Campanian municipalities and in the presence of over 300 dumping grounds (89 legal and 138 illegal) confirmed that the highest rates of CMs and mortality were found in areas with high concentrations of illegal dumps. The positive correlation found between health and waste was statistically significant, and the data collected had permitted a categorization of municipalities in groups of increasing intensity of exposure to waste.

Fig. 5. Results of the pilot study: geographical dislocation of waste disposal sites (left) and municipalities showing an excess of risk for mortality and CMs (right) (Source: WHO Regional Office for Europe et al, 2007, 3).

\footnotetext{
57 Nunzia Linzalone and Fabrizio Bianchi, "Studi sul rischio per la salute umana in prossimità di discariche di rifiuti: aggiornamento e prospettive", Epidemiol. Prev. 29 (5: 2005): 51-53.

58 For a summary of these studies, see: Linzalone and Bianchi, "Studi sul rischio", 52.
} 
While underlining limitations on completeness and accuracy, which, it has to be noted. went in any case in the direction of underestimating the risk, the study's authors went as far as to suggest an "important role" of illegal waste dumps on health effects. When combined with indicators of socio-economic deprivation, the data revealed that the most affected populations were those characterized by a lower socio-economic condition: in particular, the town of Acerra was included in the group with the highest risk. ${ }^{59}$

Some of the results of the study's intermediate stages were reported at a conference organized by the Italian Epidemiological Association in late October 2006 in Sicily. ${ }^{60}$ The study's final results were made public in April 2007 in Naples, during a public meeting and the report was made available for consultation through the World Wide Web, that is before it could be peerreviewed and published (that would only occur two years later, in the journal Occupational and Environmental Medicine). ${ }^{61}$ The decision to post the report online was controversial and caused a bitter procedural diatribe with an office of the Ministry of Health, as we will see. In the same period, the spotlight of national media moved back to Campania, as the mobilization against the reopening of a number of dumps turned violent as citizens trying to prevent garbage trucks from entering the new sites clashed with police. ${ }^{62}$

The alarming results of the multi-institutional study prompted the Commissioner and Director of Civil Protection to ask the region to commission a larger epidemiological investigation,

59 WHO Regional Office for Europe et al, "Trattamento dei rifiuti in Campania. Correlazione tra rischio ambientale da rifiuti, mortalità e malformazioni congenite Rapporto sintetico", 2007

(http://www.protezionecivile.gov.it/resources/cms/documents/sintesi_dello_studio.pdf, accessed 20 October 2015); Roberta Pirastu (ed.), "Trattamento dei rifiuti in Campania. Impatto sulla salute umana", Epidemiol. Prev. 32 (4-5: 2008): 194-6.

60 Lucia Fazzo et al, “Analisi dei cluster di mortalità in un'area con una diffusa presenza di siti di smaltimento di rifiuti urbani e pericolosi in Campania”. In: XXX Congresso AIE. 4-6 October 2006, Terrasini (Palermo): 92; Fabrizio Minichilli et al, "Rischio di malformazioni congenite nei comuni delle province di Napoli e Caserta". In: XXX Congresso AIE. 4-6 October 2006, Terrasini (Palermo): 29.

${ }_{61}$ Marco Martuzzi et al, "Cancer mortality and congenital anomalies in a region of Italy with intense environmental pressare due to waste". Occup. Environ. Med. 66 (2009): 725-73.

62 Patrizia Capua, “Campania, scontri alla discarica. Amato: solo spintonamenti”, la Repubblica, 13 May 2007; Ottavio Lucarelli, "Secondigliano, un prete denuncia 'Roghi perfino intorno alle chiese”, la Repubblica Napoli, 17 May 2007. 
the Sebiorec Study, aimed at measuring the absorption of pollutants (such as dioxins - a category of endocrine disruptors - and heavy metals) in the blood and maternal milk of a sample of the population residing in sixteen Campanian municipalities. The study, including over 850 participants, was one the largest of its kind in Europe. It also included a questionnaire on individuals' lifestyles, environments, medical histories, dietary habits, and working and reproductive histories. So, together with clinical data, also socio-anthropologic data could be collected. ${ }^{63}$ In addition biomonitoring, unlike simple data on cancer occurrence or environmental pollutants, made it possible to describe the detailed circumstances of toxic exposure in the territory. The results of Sebiorec were planned to be ready by 2009, but difficulties in collecting procedures postponed the end of the study until December $2010 .^{64}$

Aside from the launch of Sebiorec, certainly a laudable initiative but only in the medium term, little was made of the study's results in the shorter term with respect to land reclamation-let alone with respect to science communication. Following the 2007 report's release, the Ministry of Health raised some criticism on the study's methodology and the inadequacy of the communication process, but the question did not cause much clamor. ${ }^{65}$ While epidemiologists were busy starting up the Sebiorec machine, Naples was going through one of the peaks of the waste crisis: it was again the piles of rubbish bags that were monopolizing media attention. But the quiet did not last: in July 2008, a few months after the fall of the center-left government led by Romano Prodi and the assignment of a new, center-right one, led by Silvio Berlusconi, the multiinstitutional report was vehemently attacked by the Director of the Chronic Diseases Prevention Office at the Ministry of Health, Paolo D’Argenio.

According to D'Argenio, the study was misconceived, methodologically wrong, based on

63 The results of this sociological study are reported in: Cori and Pellegrino (ed.), Corpi in trappola.

${ }^{64}$ Regione Campania et al, "Studio epidemiologico sullo stato di salute e sui livelli di accumulo di contaminanti organici persistenti nel sangue e nel latte materno in gruppi di popolazione a differente rischio d'esposizione nella Regione Campania - SEBIOREC - Rapporto finale - Dicembre 2010" (available on L'Espresso magazine's website: http://www.iss.it/binary/sebi/cont/SEBIO REC_Final_report_Dec_2010_human_rev_1.pdf, accessed 20 October 2015); De Felip et al, "Priority persistent contaminants in people dwelling in critical areas of Campania Region, Italy (SEBIOREC biomonitoring study)”, Science of the Total Enviroment 487 (2014): 420-35.

65 Pietro Comba, "La risposta degli autori dello studio", Epidemiol. Prev. 32 (4-5: 2008): 192. 
false assumptions, and had therefore obtained unsubstantiated results. In short, it had been absolutely useless, and the contributors' money would have better been used for some less partisan activity. However, he wrote, it had been "sanctified by groups and associations of citizens, and had entered the public debate as an incontrovertible proof of the existence of a link between exposure and damage." ${ }^{66}$ We do not know why it took so long for D'Argenio to express his criticism of the study: what we do know is that, starting from 1 August 2008, he left his post at the Ministry of Health and became a director of the Regional Health Agency of Campania. ${ }^{67}$ D'Argenio's criticism of the 2007 study centered on three aspects. First of all, he contested the study's methodology: the data used for assessing CM were incomplete, he argued, since for a long time many Campanian hospitals had not collaborated with the regional CM Record Office; as a consequence, areas where hospitals had indeed collaborated had been given a much higher weight than those where they had not. In sum, the analysis may have been "distorted by a gigantic selection bias that destroyed the credibility of the results." 68

Second, as for mortality clusters, according to D'Argenio, the coincidence of the wasteexposed area and the highest mortality area "did not explain anything," as confounding factors had not been adequately considered. Instead, he argued, it had been known ever since the 1990s, when the ISS had published an “important report” (which, however, D'Argenio did not cite), that mortality in Campania showed excesses in the Provinces of Naples and Caserta: an excess that was linked, amongst other diseases, to lung cancer. Where were the main causes of lung cancer to be found then? Not in illegal waste, but in tobacco smoke and traffic pollution. The index of municipal socio-economically deprivation, D'Argenio maintained, was not sufficient to account for high death rates: these could be explained away by the fact that in those areas there were more smokers, people smoked in public places where it was forbidden, more motorcyclists rode without their helmets, and traffic was out of control. ${ }^{69}$

${ }^{66}$ Paolo D'Argenio, "Critiche allo studio 'Trattamento dei rifiuti in Campania: impatto sulla salute umana”, Epidemiol. Prev. 32 (4-5: 2008): 191.

67 Paolo D’Argenio, Curriculum Vitæ (http://www.ausl-cesena.emr.it/Portals/0/Documenti/AmmTrasparente/ ConsulentiCollaboratori/Curricula/C_Dargenio_Europass_2013.pdf, accessed 20 October 2015).

${ }^{68}$ D’Argenio, "Critiche allo studio", 190.

69 Ibid, 191. 
Finally, in the opinion of the officer of the Ministry of Health, the communication strategy had been wrong. The report's misuse of the study by science popularizers, environmentalist associations, and the media, which, he maintained, had contributed to a wall between the public opinion and civic institutions and mistrust in the population, exactly at the time when the situation of public order was worsening. According to D'Argenio, the publication of the results on the Web in 2007 had been a blunder: the commentary posted alongside it had confused relative and absolute risk. In addition, science writers flirting with radical left-wing associations, led by demagogical figures claiming to protect people from invisible threats, had misinterpreted the data, thus generating the mentioned "widespread conviction" in the population, and ultimately a NIMBY effect. $^{70}$

The authors of the report responded to all of D'Argenio's criticisms with a flat rejection: some of his arguments may in principle be correct, they acknowledged, but had been already covered in the authors' previous publications, or had been long discussed by them; others, like the one on the role of smoke, needed not just to be advanced, but proved through evidence, and studies, and D'Argenio had not done that. Other arguments still, such as the one on communication, sounded specious: the authors retorted that the communicators' task was to be faithful to scientific reality, and also to highlight science's uncertainties. They were implicitly stating that patronizing populations through false reassurances would be dishonest. ${ }^{71}$

D'Argenio's position exemplified the institutional view of the role of citizens in the issue. The rationality of the experts was contrasted to the populace's emotional distortion of facts, and the media were accused of communicating poorly in a setting where the Ministry of Health had not bothered to disseminate any information to the public. Ultimately, D'Argenio conveyed the message that, because of these biases, the report had not proven any link between waste and health: as a consequence, any claim of the existence of such a link was preposterous, and governmental officers like him may as well not take the study's results into account. ${ }^{72}$ Such a

\footnotetext{
70 Ibid, 192.

71 Comba, "La risposta degli autori dello studio", 192-3.

72 D’Argenio, "Critiche allo studio", 191.
} 
recommendation was, in fact, superfluous, since a similar position had already been expressed by Donato Greco, Director of the Prevention Department at the Ministry of Health. In the winter of 2008, Greco had become "the public face of denial," when declaring to newspapers that the population should not be worried, given the absence of any causal link between dumps and health. And in the spring, in an article where CNR's Fabrizio Bianchi strongly recommended the launch of a program of land reclamation even in a situation of epidemiological uncertainty, Greco scoffed at that suggestion, ascribing any talk of a link to "the ignorance of innocent populations, the incompetence of some among [his] colleagues, and the illegality of those who [made] a profit from the waste business." 73

Whereas Bianchi maintained a more scientifically correct position, by stressing the uncertainties intrinsic to science, Greco's patronizing attitude was epistemologically weak, but as a main representative of a governmental institution he could enjoy a much larger media attention than Bianchi. In addition, it was repeatedly reported by the media, which did not bother to clarify that whereas Greco and D'Argenio were dissenters who had not carried out any epidemiological work on the Campanian territory, the authors of the multi-disciplinary study came from highreputed institutions and had carried out research on the Campanian situation. Greco claimed the results were uncertain; that no reliable link had been found between landfills and health.

Essentially, officers at the Ministry of Health were "us[ing] normal scientific uncertainty to undermine the status of actual scientific knowledge." ${ }^{94}$ They were producing scientific ignorance. ${ }^{75}$ But the authors of the 2007 report had found a link, and the data were growing increasingly accurate, in the direction of establishing a causal relationship.

D'Argenio returned to the fray in early 2009, when he launched a new attack on the 2007 study, no longer focusing on the communication strategy, but on a procedural aspect ${ }^{76}$ : the report's results had been disclosed not through a peer-reviewed journal, but directly to the public, in a

73 Conchita Sannino, "Rifiuti, l'allarme degli esperti 'Una maxi-area da bonificare'”, la Repubblica Napoli, 25 April 2008.

74 Oreskes and Conway, Merchants of Doubt, 34.

75 Oreskes and Conway, Merchants of Doubt; Markowitz and Rosner, Deceit and Denial.

76 Paolo D'Argenio, “Ulteriori critiche allo studio di Comba et al. su salute e rifiuti in Campania”, Epidemiol. Prev. 33 (1-2: 2009): 3. 
"Pasteurian" style. ${ }^{77}$ That was a reasonable point to raise, but the authors had an equally reasonable response, and it touched upon the ethos of epidemiology: although the need to publish in a peerreviewed journal was acknowledged (and, in fact, the peer-reviewing process was ongoing for the results of the report), ISS's Pietro Comba affirmed that "researchers should not, while waiting for incontrovertible evidence, postpone decisions or, worse, interpret the absence of evidence as the proof of absence of risks". ${ }^{78}$ That was exactly what the governmental experts were doing.

Eventually, however, the attempt to infantilize the affected communities by propagating a narrative of absence of risks backfired. In such an acute political and governance crisis, and in the presence of publicly known data on waste and health, the more passionately governmental experts denied any risk, the less the population trusted them.

On 31 December 2009, the state of emergency related to Campanian waste management was declared over (see above). Was the epidemiological controversy closed by then? In a way, it was. But not in the way one would have expected. By the very time epidemiology had proven the link between waste and health, the government had decided to behave as though there was no such link. It just silenced the question, aided by the militarization of the landfill areas, which, at the expense of citizens' democratic rights, made it easier for the government to remove garbage from towns and dispose it indiscriminately in new landfills.

The government, not the epidemiological community, was in charge of devising a solution to the crisis, and the chosen solution was to pretend that, with less rubbish in the streets, health problems would no longer be a focal point. By removing 170,000 tons of garbage from the streets of Naples and its province, the government claimed the case to be closed. For the government, the militarization of the landfill territories and the cleanup of streets was meant to signify the depoliticization of the whole waste issue, its transformation into an non-issue, its "falling back to sleep," to use Bruno Latour's words. ${ }^{79}$

77 The reference is to: Bruno Latour, Pasteur : guerre et paix des microbes: suivi de, Irréductions (Paris: Découverte/Poche, 2001).

78 Pietro Comba, "La risposta dgli autori”, Epidemiol. Prev. 33 (1-2: 2009): 3-4. The quote is from p. 4.

79 Bruno Latour, “Turning Around Politics - A Note on Gerard de Vries' Paper". Social Studies of Science 37 (5: 2007 ): 818. See also, for a Latourian perspective over waste management: Myra J Hird et al., "Making waste management public (or falling back to sleep)", Soc. Stud. Sci. 44 (3: 2014): 441-65. 
However, D'Alisa and Armiero argue, “the government's obsession with urban waste and cleanup operation have been instrumental in concealing the actual contamination caused by toxic waste"; in addition, the quantitative analysis they make of the flows of produced waste and regional landfills' capacities reveals that two million tons of garbage went missing, and this is highly worrying in a territory characterized by heavy eco-mafias' activities and illegal disposals. ${ }^{80}$

A final point should be raised with respect to the results of the Sebiorec study, which were released in late 2010 . The study eventually proved that, while the rate of pollutants contained in blood and milk was not significantly higher than the levels measured in other non-industrial environments, a number of harmful substances (arsenic, lead, mercury) were indeed detected. Living close to illegal dumps for dangerous waste was found to indicate higher exposure to organic substances such as dioxins, furans, and polychlorinated biphenyls, due to the practice of arson. As noted by CNR communicator, Liliana Cori, who took part in the sociological component of Sebiorec, the most important result for a study aimed at understanding the distribution of the levels of exposure to pollutants was the great variability of values among different areas observed for the analyzed substances, which could help designing targeted disposal strategies and prevention schemes. ${ }^{81}$

\section{Conclusions}

The analysis of the Campanian epidemiological debate allows us to pinpoint two distinct moments, characterized by similar dynamics and different outcomes, both of which fit within the framework of studies on the production of knowledge and ignorance. The first concerns the publication of the "triangle of death" article in the summer of 2004. The article was highly mediatized, but its

80 The quote is from: D'Alisa and Armiero, "What happened to the trash?", 30; Id., "La ciudad de los residuos", passim.

${ }^{81}$ Fabrizio Bianchi and Liliana Cori, "Per una dimensione ecologica dell'epidemiologia", in Cori and Pellegrino (ed.), Corpi in trappola, 273. 
methodology and form of publication (a non peer-reviewed report) were stigmatized by the Italian epidemiological community. Although the authors of the report may have erred in their methodology and communication strategy, they were not aiming to produce deliberately inaccurate results. Be that as it may, the inaccuracies contained in the report shaped a biased public perception of the geographical borders of the most "toxified" area. The image of the triangle of death is still central to contemporary narratives about the Campanian waste crisis, and further studies — whether simultaneous to, preceding, or following the Lancet's — did not have an equivalent impact on public perception. On a positive side, however, the loud alarm bell rung by the report raised public awareness of toxic waste in Campanian lands, and its possible links to human health.

The second moment of the debate, starting with the publication of the multi-institutional study in 2007, generated an altercation between the two camps, "deniers" and "precautionists": the former absolutely denying any sort of link between health and waste dumps, the latter affirming the existence of some link, while stressing the uncertainties of the science involved. The two camps were clearly divided into governmental (denier) and non-governmental (precautionist) experts. The first camp included agents from the Ministry of Health; the second, a much larger spectrum including experts from CNR, ISS, and WHO. Despite their numerical inferiority, and thanks to the power conferred to them by being governmental representatives, deniers managed to fabricate doubt about the health-waste association.

The debate centered on two elements in particular: a methodological one and a procedural one. The methodological element regarded the definition of the area in which to lead a study and the choice of units for clusters analysis. The procedural element regarded the dissemination of scientific results before peer review. The dispute had practical consequences, in that, sticking to a paradigm that held the absence of unambiguous evidence of risks to be evidence of absence of such risks, government experts tried to reassure the population. Can these experts be said to have been producing ignorance? In its weaker meaning of deliberately denying reliably increasing 
evidence that was accumulating around the health-to-waste relation, they can. In a stronger and more literal version of "ignorance production," the claim would only be partially accurate, in that these experts were in fact not producing their own scientific evidence to disprove others' claims. In the presence of a scientific controversy, ultimately, such attempts at reassurance beyond reasonable doubt proved counterproductive, as citizens perceived they were being deliberately denied the truth by the institutional representatives.

Whereas the citizens' mobilization against landfills and incinerators developed throughout the epidemiological debate, its intensity only decreased following the government's decision to militarize sensitive areas and declare demonstrations there illegal. Such militarization, joined to the esthetic and much mediatized operation of the cleanup of the Campanian capital city, represented the ultimate sign that the controversy — or rather, its public face — had fallen back to sleep.

\section{Acknowledgments}

I would like to thank Ximo Guillem Llobat and José Ramón Bertomeu Sánchez for organizing the "Living in a Toxic World" Summer School, which allowed me to present the research whence this paper stems.

\section{Bibliography}

Agamben G, Stato di eccezione. Torino: Bollati Boringhieri, 2003

AIE, "Trattamento dei rifiuti e salute. Posizione dell'Associazione italiana di epidemiologia. 6 maggio 2008", Epidemiol. Prev. (4-5: 2008): 183-7

Altavista P, Belli S, Bianchi F, Binazzi A, Comba P, Del Giudice R, Fazzo L, Felli A, Mastrantonio M, Menegozzo M, Musmeci L, Pizzuti R, Savarese A, Trinca S, Uccelli R, "Mortalità per causa in un'area della Campania con numerose discariche di rifiuti", Epidemiol. Prev. 28 (6: 2004): 311-21.

Amato V, "Conflitti ambientali e territorio. Alcune evidenze dalla crisi dei rifiuti in Campania", in Il cavallo di Troia. Disagio sociale, politiche carenti, marginalità diffusa nello sviluppo territoriale della Campania, edited by T D'Aponte. Roma: Aracne, 2009. 87-106

Armiero M (ed.), Teresa e le altre. Storie di donne nella terra dei fuochi. Milano: Jaca Book, 2014 
Armiero M, “Seeing Like a Protester”, Left History 13 (1: 2008): 59-76

, "La natura sotto casa: le lotte per la giustizia ambientale con un caso di studio sulla Campania”, Ricerche Storiche XLI (3: Sep-Dec 2011): 551-63

, "Garbage Under the Volcano: The Waste Crisis in Campania and the Struggles for Environmental Justice", in A History of Environmentalism. Local Struggles, Global Histories, edited by M Armiero and L Sedrez. London/New York: Bloomsbury, 2014. 167-84

Armiero M, D’Alisa G, "Voices, Clues, Numbers: Roaming Among Waste in Campania", Capitalism Nature Socialism 24 (4: 2013): 1-10

, "Rights of Resistance: The Garbage Struggles for Environmental Justice in Campania, Italy", Capitalism Nature Socialism 23 (4: 2012): 52-68

Barbagallo F, Il potere della camorra (1973-1998). Torino: Einaudi, 1999

Bauman Z, Wasted Lives: Modernity and Its Outcasts. Hoboken: Wiley, 2014

Bianchi F, Comba P, Martuzzi M, Palombino R, Pizzuti R, "Italian 'Triangle of death"”, The Lancet Oncology 5 (December 2004): 710

Bianchi F, Cori, L, "Per una dimensione ecologica dell'epidemiologia", in Corpi in Trappola - Vite e Storie tra i Rifiuti, edited by L Cori and V Pellegrino. Roma: Editori Riuniti, 2011. 263-89

Bianchi F, Minichilli F, “Mortalità per linfomi non Hodgkin nel periodo 1981-2001 in 25 comuni italiani con inceneritori di rifiuti solidi urbani”, Epidemiol. Prev. (2: 2006): 80-1

Bianchi F, et al, "Waste in Campania region, Italy", presented at: XXVII IEA World Congress of Epidemiology: Epidemiology and equity in health: methodological challenges an strategies for the $21^{\text {st }}$ century, Bangkok, 21-25 August 2005

Bolognini M, Garetti G, Gennaro V, Gentilini P, Ghirga G, Guerra M, Migaleddu V, Mocci M, Panizza C, "Critiche al seminario OMS-Europa sui rifiuti", Epidemiol. Prev. (2: 2008): 79-80;

Bolognini M, Garetti G, Gennaro V, Gentilini P, Guerra M, Migaleddu V, Panizza C, Vantaggi G, "Lettera aperta ai colleghi dell'AIE sul documento 'Trattamento dei rifiuti e salute". Epidemiol. Prev. (4-5: 2008): 188.

Boudia S, Jas N. (eds.), Toxicants, Health and Regulation since 1945. London: Pickering \& Chatto, 2013 , Powerless Science? Science and Politics in a Toxic World. London: Berghahn Books, 2014

Bradford Hill A, "The Environment and Disease: Association or Causation?" Proceedings of the Royal Society of Medicine 58, no. 5 (May 1965): 295-300

Bullard R, Dumping in Dixie: race, class, and environmental quality. Boulder: Westview Press, 1990

Caldiroli M, "Impatto ambientale dei processi di incenerimento di rifiuti", Epidemiol. Prev. (1: 
Cantoni R, "Comunicare il rischio per la salute durante l'emergenza rifiuti in Campania: la fase 2004-2008”. Master's dissertation in Science Communication, SISSA-ISAS, Trieste, 2011

Carolan MS, "Sustainable agriculture, science and the co-production of 'expert' knowledge: The value of interactional expertise", Local Environment 11 (4: 2006): 421-31

Catton WR Jr, Dunlap RE, “Environmental Sociology: A New Paradigm”, The American Sociologist 13 (February 1978): 41-49

Collins HM, Evans R, "The Third Wave of Science Studies: Studies of Expertise and Experience”, Social Studies of Science 32 (2: April 2002): 235-96 , Rethinking Expertise. Chicago: University of Chicago Press, 2007

Colombo C, "Sono tutte ecoballe. Come uscire dall'emergenza rifiuti in Campania?", Epidemiol. Prev. 29 (1: 2005): 61-2

Comba P, “La risposta degli autori dello studio”, Epidemiol. Prev. 32 (4-5: 2008): 192-3 , "La risposta dgli autori”, Epidemiol. Prev. 33 (1-2: 2009): 3-4

Comba P, Bianchi F, Fazzo L, Martina L, Menegozzo M, Minichilli F, Mitis F, Musmeci L, Pizzuti R, Santoro M, Trinca S, Martuzzi M, "Cancer Mortality in an Area of Campania (Italy) Characterized by Multiple Toxic Dumping Sistes", Annals of the New York Academy of Sciences 1076 (September 2006): 449-61

Corburn J, Street Science. Community Knowledge and Environmental Health Justice. Cambridge, MA: MIT Press, 2005

, "Community knowledge in environmental health science: co-producing policy expertise", Envir. Sci. Pol. 10 (2: 2007): 150-61

Cori L, "Finalità e criticità del processo di comunicazione", in Indagini epidemiologiche nei siti inquinati: basi scientifiche, procedure metodologiche e gestionali, prospettive di equità. Rapporti ISTISAN 06/19 Rev., edited by F Bianchi and P Comba. Roma: Istituto Superiore di Sanità, 2006. 85-114

Cori L, and Pellgrino V, Corpi in Trappola - Vite e Storie tra i Rifiuti. Roma: Editori Riuniti, 2011

D'Alisa G, Armiero M, "La ciudad de los residuos. Justicia ambiental e incertidumbre en la crisis de los residuos en Campania (Italia)", Ecología política 41 (2011): 97-105

, "What Happened to the Trash? Political Miracles and Real Statistics in an Emergency Regime”, Capitalism Nature Socialism 24 (4: 2013): 29-45

D’Alisa G, Burgalassi D, Healy H, Walter M, "Conflict in Campania: Waste emergency or crisis of democracy”, Ecological Economics 70 (2010): 239-49

D’Alisa G, Di Nola MF, Giampietro M, “A multi-scale analysis of urban waste metabolism: density of waste disposed in Campania", Journal of Cleaner Production 35 (2012): 59-70 
D'Argenio P, "Critiche allo studio 'Trattamento dei rifiuti in Campania: impatto sulla salute umana"”, Epidemiol. Prev. 32 (4-5: 2008): 189-92.

, "Ulteriori critiche allo studio di Comba et al. su salute e rifiuti in Campania", Epidemiol. Prev. 33 (1-2: 2009): 3-4

De Felip E, Bianchi F, Bove C, Cori L, D’Argenzio A, D’Orsi G, Fusco M, Miniero R, Ortolani R, Palombino R, Parlato A, Pelliccia MG, Peluso F, Piscopo G, Pizzuto R, Porpora MG, Protano D, Senofonte O, Russo Spena S, Simonetti A, Di Domenico A, "Priority persistent contaminants in people dwelling in critical areas of Campania Region, Italy (SEBIOREC biomonitoring study)", Science of the Total Enviroment 487 (2014): 420-35

Di Costanzo G, Ferraro S, "The Landfill in the Countryside: Waste Management and Government of the Population in Campania", Capitalism Nature Socialism 24 (4: 2013): 17-28

Dunlap RE, Catton WR Jr, “Environmental Sociology”, Annual Review of Sociology 5 (1979): 243273

Epstein S, "The Construction of Lay Expertise: AIDS Activism and the Forging of Credibility in the Reform of Clinical Trials", Sci. Technol. Hum. Val. 20 (4: 1995): 408-37

Fazzo L, et al, “Analisi dei cluster di mortalità in un'area con una diffusa presenza di siti di smaltimento di rifiuti urbani e pericolosi in Campania", presented at: XXX Congresso AIE, 4-6 October 2006, Terrasini (Palermo), communication n. 92

Funtowicz SO, Ravetz JR, "A new scientific methodology for global environmental issues", in Ecological Economics: The Science and management of Sustainability, edited by R Costanza. New York: Columbia University Press, 1991. 137-52

__ "Science for the post-normal age”, Futures 25 (7: 1993): 739-55

Hird MJ, Lougheed S, Kerry Rowe R, Kuyvenhoven C, "Making waste management public (or falling back to sleep)", Soc. Stud. Sci. 44 (3: 2014): 441-65

Homsy GC, "Climate Change and the Co-Production of Knowledge and Policy in Rural USA Communities", Sociol. Ruralis. 53 (3: 2013): 291-310

Iacuelli A, Le vie infinite dei rifiuti: il sistema campano. Altrenotizie.org/Lulu, 2007

ISPRA, Rapporto Rifiuti Urbani, Edizione 2014 - Dati di sintesi, vol. 202/2014. Roma: ISPRA, 2014

Latour B, "Turning Around Politics - A Note on Gerard de Vries' Paper". Social Studies of Science 37 (5: 2007): 811-20

Le Roux T, Le laboratoire des pollutions industrielles: Paris, 1770-1830. Paris: Albin Michel, 2011

Linzalone N, Bianchi F, "Studi sul rischio per la salute umana in prossimità di discariche di rifiuti: aggiornamento e prospettive", Epidemiol. Prev. 29 (5: 2005): 51-3

, "Inceneritori: non solo diossine e metalli pesanti, anche polveri fini e ultrafini", Epidemiol. 
Prev. (1: 2007): 62-6

, "Il contributo della VIS nella definizione delle politiche di gestione dei rifiuti a partire dal caso degli inceneritori”, Epidemiol. Prev. (3: 2009): 113-5

Lolive J, “La montée en généralité pour sortir du NIMBY. La mobilisation associative contre le TGV Méditerranée", Politix 10 (39: 1997): 109-30.

Maccuglia F, "La Campanie, plaque tournante du trafic de déchets". Historiens \& Géographes 403 (2008): 125-33

Markowitz G, Rosner D, Deceit and Denial. The Deadly Politics of Industrial Pollution. New York: University of California Press and Milbank Books, 2002

, Lead Wars. The Politics of Science and the Fate of America's Children. New York: University of California Press and Milbank Memorial Fund, 2013

Martinez-Alier J, The Environmentalism of the Poor: A Study of Ecological Conflicts and Valuation. Northhampton, MA: Edward Elgar Publishing, 2002

Martuzzi M, et al, "Health impact assessment of waste in Campania, southern Italy", presented at: IAIA, Boston, MA, 31 May - 3 June 2005

Martuzzi, M, et al, "Waste and health in souther Italy", presented at: ISEE, Johannesburg, 13-16 September 2005

Martuzzi M, et al, "Patología neoplástica y malfomaciones congénitas en las Provincias de la Campania con mayor presenzia [sic] de [sic] descargas", in Salud ocupacional y ambiental: realidades diversas, Memorias de la conferencia international: Salud ocupacional y ambiental: emergencias en los países en desarrollo, Quito, 6-10 March 2006, edited by P Landrigan et al (eds.). Quito: IFA, 2006. 269-74

Martuzzi M, et al, "Waste and health in southern Italy", presented at: Spatial Epidemiology Conference, London, 23-25 May 2006

Martuzzi M, Bianchi F, Comba P, Fazzo L, Martina L, Menichilli F, Mitis F, Pizzuti R, Santoro M, "Patologia neoplastica e malformazioni congenite nelle province della Campania con maggiore presenza di discariche", Notiziario Istituto Superiore di Sanità 18 (6: 2005): 3-8

Martuzzi M, Mitis F, Bianchi F, Minichilli F, Comba P, Fazzo L, "Cancer mortality and congenital anomalies in a region of Italy with intense environmental pressare due to waste", Occup. Environ. Med. 66 (2009): 725-73

Minichilli F, et al, "Rischio di malformazioni congenite nei comuni delle province di Napoli e Caserta", presented at: XXX Congresso AIE. 4-6 October 2006, Terrasini (Palermo), comm. n. 29

Moore SA, "The Politics of Garbage in Oaxaca, Mexico", Society and Natural Resources 21 (2008): 597-610

Oreskes N, Conway EM, Merchants of Doubt: How a Handful of Scientists Obscured the Truth on Issues from Tobacco Smoke to Global Warming. London: Bloomsbury Press, 2010 
Pasotti E, "Sorting through the Trash: The Waste Management Crisis in Southern Italy", South European Society and Politics 15 (2: 2010): 289-307.

Petrillo A (ed.), Biopolitica di un rifiuto. Le rivolte anti-discarica a Napoli e in Campania. Verona: Ombre corte, 2009

Petrillo A, "Le urla e il silenzio. Depoliticizzazione dei conflitti e parresia nella Campania tardoliberale", in Biopolitica di un rifiuto. Le rivolte anti-discarica a Napoli e in Campania, edited by A Petrillo. Verona: Ombre corte, 2009. 17-71

Roberta Pirastu (ed.), "Trattamento dei rifiuti in Campania. Impatto sulla salute umana", Epidemiol. Prev. 32 (4-5: 2008): 194-6

Proctor RN, Schiebinger L, Agnotology: The Making and Unmaking of Ignorance. Stanford: Stanford University Press, 2008

Rabitti P, Ecoballe. Tutte le verità su discariche, inceneritori, smaltimento abusive dei rifiuti. Testimonianza shock su Napoli e Campania. Reggio Emilia: Aliberti Editore, 2008

Rip A, “Controversies as informal technology assessment”, Social Policy 14 (1983): 3-18

Ruggiero S, "Chiaiano e i nuovi irregolari", in Biopolitica di un rifiuto. Le rivolte anti-discarica a Napoli e in Campania, edited by A Petrillo. Verona: Ombre corte, 2009. 94-108

Savarese R, Galli sulla monnezza. Silenzi, grida e bugie sui rifiuti in Campania. Roma: Franco Angeli, 2009

Saviano R, Gomorra. Viaggio nell'impero economico e nel sogno di dominio della camorra. Milano: Mondadori, 2006

Senior K, Mazza A, "Italian 'Triangle of death' linked to waste crisis”, The Lancet Oncology 5 (September 2004): 525-7

Tarantino C, "Strane confessioni. Memoria su alcuni casi di licenziosità nella Napoli del XXI secolo", in Biopolitica di un rifiuto. Le rivolte anti-discarica a Napoli e in Campania, edited by A Petrillo. Verona: Ombre corte, 2009. 189-222

Terracini B, "Discariche, triangoli e aree calde", Epidemiol. Prev. 28 (6: 2004): 299-300

Trinca S, Comba P, Felli A, Forte T, Musmeci L, Piccardi A, "Childhood mortality in an area of southern italy with numerous dumping grounds: application of GIS and preliminary findings", presented at: First European Conference 'Geographic Information Sciences in public Health'. University of Sheffield, Sheffield, 19-20 September 2001

Trom D, "De la réfutation de l'effet NIMBY considérée comme une pratique militante. Notes pour une approche pragmatique de l'activité revendicative", Revue française de science politique 49 (1: 1999): $31-50$

\section{Web sources}

APAT, Rapporto rifiuti 2007, La produzione dei rifiuti in Italia - Tabelle, 
Armiero M, "Is there an indigenous knowledge in the urban North? Re/inventing local knowledge and communities in the struggles over garbage and incinerators in Campania, Italy", Estudos de Sociologia 1 (20: 2014) [no page number], http://www.revista.ufpe.br/revsocio/index.php/revista/article/view/339/298, accessed 19 October 2015

Istituto Nazionale di Statistica, 'Pil pro capite', http://noiitalia.istat.it/index.phpid=7\&user_100ind_pi1\%5Bid_pagina\%5D=91, accessed 19 October 2015

Legambiente, Rapporto Ecomafia 2014, http://www.legambiente.it/contenuti/dossier/rapportoecomafia-2014, accessed 21 October 2015

Regione Campania/ISS/CNR, "Studio epidemiologico sullo stato di salute e sui livelli di accumulo di contaminanti organici persistenti nel sangue e nel latte materno in gruppi di popolazione a differente rischio d'esposizione nella Regione Campania - SEBIOREC - Rapporto finale Dicembre 2010", 2010, http://speciali.espresso.repubblica.it/pdf/sebiorec2010.pdf, accessed 21 October 2015.

WHO Regional Office for Europe/ISS/CNR/Regione Campania, "Trattamento dei rifiuti in Campania: impatto sulla salute umana. Studio Pilota. Malformazioni congenite nelle province di Napoli e Caserta (1996-2002): analisi descrittiva e struttura spaziale del rischio", 2005. Synthesis available at: http://www.epicentro.iss.it/temi/ambien-te/notepernapoli26012005.pdf, "Trattamento dei rifiuti in Campania: impatto sulla salute umana. Studio Pilota. Sintesi dei risultati e indicazioni preliminari", accessed 20 October 2015

, "Trattamento dei rifiuti in Campania: impatto sulla salute umana. Studio Pilota. Mortalità per tumori nelle province di Napoli e Caserta (1994-2001): analisi descrittiva e struttura spaziale del rischio", 2005. Ssynthesis available at: http://www.epicentro.iss.it/temi/ambiente/notepernapoli26012005.pdf, "Trattamento dei rifiuti in Campania: impatto sulla salute umana. Studio Pilota. Sintesi dei risultati e indicazioni preliminari” accessed 20 October 2015

, "Trattamento dei rifiuti in Campania: impatto sulla salute umana. Studio Pilota. Sintesi dei risultati e indicazioni preliminari”, 2005, http://www.epicentro.iss.it/temi/ambiente/notepernapoli26012005.pdf, accessed 20 October 2015

, "Trattamento dei rifiuti in Campania. Correlazione tra rischio ambientale da rifiuti, mortalità e malformazioni congenite. Rapporto sintetico", 2007, http://www.protezionecivile.gov.it/ resources/cms/documents/sintesi_dello_studio.pdf, accessed 20 October 2015 